Seminário de Pesquisa

Programa de Pós-Graduação

Design FAU USP

\title{
Design: Sistema de sinalização pública para inclusão de deficientes visuais
}

\author{
Cristine Porto Brondani, Denise Dantas
}

\author{
sistemas de sinalização; deficiencia visual; design centrado \\ no usuário; mobilidade; tecnologias assistivas
}

Esta pesquisa se insere no contexto de recente documento elaborado pelo Conselho Brasileiro de Oftalmologia (CBO 2019), no qual estimase que a cegueira afete 39 milhões de pessoas em todo o mundo e que 246 milhões sofram de perda moderada ou severa da visão. Com tema endereçado em design de sinalização para mobilidade e autonomia de pessoas com deficiência visual, o objetivo é identificar a partir de uma investigação qualitativa, aspectos relevantes no que diz respeito aos sistemas de sinalização de espaços de circulação

Curso

Mestrado

\section{Linha de Pesquisa}

Design: Processos e Linguagens

\section{Cristine Porto Brondani}

BRONDANI, Cristine Porto; Mestranda do programa de Pósgraduação em Design da FAU USP, Especialista em Engenharia de Produção - Ergonomia pela UFRGS (2006) e Bacharel em Desenho industrial - Projeto de Produto pela Universidade Franciscana de Santa Maria RS (2004).

e-mail: cristine@usp.br Lattes: http://lattes.cnpq. br/1678899327446019

Orcid: https://orcid.org/00000003-0066-1936

\section{Denise Dantas}

Docente na Universidade de São Paulo na graduação e pós-graduação em Design, coordenadora do LabDesign FAUUSP e colíder do grupo de pesquisa Design em Ação. Realiza pesquisas em Human Centred Design, Inovação social, Materiais para o design.

e-mail: dedantas@usp.br

Lattes: http://lattes.cnpq. br/7636937300587505

Orcid: https://orcid.org/00000003-4419-6394 pública e iniciativas do Design em oferecer novas tecnologias para a informação acessível. Dado o caráter qualitativo deste estudo, a intenção é compreender o fenômeno conforme destacado por Creswell (2007). Como resultados preliminares, a pesquisa apresenta uma revisão sistemática da literatura sobre a contribuição do Design de sinalização na autonomia de pessoas cegas. Foi realizado, ainda, um pré-teste para a coleta de dados planejado em contexto remoto, em que as entrevistas foram realizadas com auxílio de tecnologias de intermediação digital. Os respondentes receberam informações referentes à pesquisa e Termo de Consentimento Livre e Esclarecido (FLICK, 2009, p. 51-52), autorizando a divulgação dos dados para fins acadêmicos. Os conteúdos foram transcritos, sistematizados e categorizados de acordo com um conjunto de técnicas com base na Análise Temática proposta por MYNAYO (2009). A pesquisa está em estágio de finalização da revisão de literatura e de planejamento da coleta de dados, e o desafio será superar as perdas em relação à observação presencial, ainda que o contexto remoto viabilize a logística e o prazo. Os próximos passos incluem levantamento dos dados, tratamento parcial da primeira parcela do conteúdo e redação do memorial de qualificação. 


\title{
Design: Public signaling system for inclusion of visually impaired users
}

\author{
Cristine Porto Brondani, Denise Dantas
}

Signaling systems; visual impairment; user centered design; mobility; assistive technologies

This research is situated in the context of the document published recently by the Conselho Brasileiro de Oftalmologia (CBO 2019), that estimates that blindness affects 39 million people in the World and that other $\mathbf{2 4 6}$ million suffer with moderate or severe visual impairment. Focused on Signaling Design for Mobility and Autonomy of visually impaired users, the objective is to identify, through a qualitative investigation, relevant topics related to signaling systems on public spaces and Design initiatives to offer new technologies to provide accessible information. Given its qualitative disposition, the objective of the study is to understand the phenomenon as highlighted by Creswell (2007). As preliminary results, the research presents a systematic literature review about the contribution of Signaling Design on visually impaired user's autonomy. Moreover, a pre-test for the remote data collection was conducted, where interviews were conducted with digital communication technologies. The respondents received information about the research and a Free and Informed Consent Term (FLICK, 2009, p. 51-52), allowing publication of data for academic purposes. The answers were transcripted, systematized and categorized in accordance with the techniques set based on thematic analysis proposed by MYNAYO (2009). The research is currently in its literature review and data collection stages and its main challenge will be to overcome eventual losses related to the absence of face-to-face observation, although the online context allows that logistics and deadlines can be attended. The next steps include the survey of the data, the treatment of the initial portion of the content and the elaboration of the qualification memorial.

\section{Referências | References \\ CBO 2016. CBO E IABP divulgam material educativo sobre o Dia Mundial da Visão. In: CBO Conselho Brasileiro de Oftalmologia <https://www.cbo.net.br/ novo/publico-geral/diamundialdavisao.php>, 15/09/2020.}

CRESWELL, J. W. 2010. Projeto de pesquisa métodos qualitativo, quantitativo e misto. Porto Alegre: Artmed.

FLICK, U. 2009. Introdução à Pesquisa Qualitativa. Porto Alegre: Artmed. MINAYO, M. C. S.; DESLANDES, S. F.\& GOMES, R. 2009. Pesquisa social: teoria, método e criatividade. Petrópolis: Vozes.

in human centered design, social innovation and materials for design.

e-mail: dedantas@usp.br

Lattes: http://lattes.cnpq. br/7636937300587505

Orcid: https://orcid.org/00000003-4419-6394 